"Desire for Justice, Desire for Law: An Ethnography of Peoples' Tribunals" edited by Chowra Makaremi and Pardis Shafafi, PoLAR: Political and Legal Anthropology Review, Vol. 42, Number 2, pp. 181-243, November 2019

\title{
Staging International Environmental Justice: The International Monsanto Tribunal ${ }^{\star}$
}

\author{
Giovanni Prete
}

University of Paris 13, Iris

\section{Christel Cournil}

Sciences Po Toulouse, Lassp

[p. 191] Opinions tribunals dealing with environmental issues have multiplied over the last several years as a consequence of the rise of international environmental law and its promo- tion by international networks. Drawing on an ethnographic investigation of one of those tribunals - the International Monsanto Tribunal- this article reflects on the many objec- tives they often pursue: strengthening political positions, publicizing environmental and health social struggles, and promoting legal theories. In our case, we show that articulat-ing those objectives involved intense work to stage the tribunal's legitimacy. We analyze this work and how it was put to the test during and after the sessions of the tribunal. Our article broadly suggests that environmental opinion tribunals are political arenas where rights and identities are not only asserted but also negotiated and legitimized. [opinion tribunal, International Monsanto Tribunal, environment, ecocide, law]

In October 2016, the International Monsanto Tribunal took place in The Hague. This event staged and mediatized a trial to assess allegations made against the multinational Monsanto, a firm whose

${ }^{*}$ For quotation purpose, the original page numbers are indicated [in bracket] in the text. 
products' impact on health and the environment have been the subject of much criticism from nongovernmental organizations (NGOs). ${ }^{1}$ Unsurprisingly, the accused firm attacked the aims of the tribunal's organizers, insisting in an open letter on its illegitimacy and biased nature. ${ }^{2}$ Some legal scholars, commenting on the tribunal organization, also questioned the court's claim to the law because it was not backed by any form of state legitimacy.

All tribunals of opinion face challenges to their legitimacy. States, firms, and legal experts regularly denounce tribunals' lack of official recognition by state authorities and international organizations, their politically biased procedures, or their inefficiency. To cope with these accusations, opinion tribunal organizers have adopted different strategies (Klinghoffer and Klinghoffer 2002). Many have insisted that their legitimacy is linked to their capacity to embody "civil society" through the diversity of their members: philosophers, writers, economists, and so on. The tactic of the International Monsanto Tribunal's organizers, however, was different. They insisted on the tribunal's proximity to a "real" court. Indeed, while it was not the first time that an industrial firm had been tried in a tribunal of opinion, the one held in The Hague was presented by its organizers as exceptional and compared to a real tribunal, "with a real judicial procedure, real judges, real lawyers, and real witnesses." ${ }^{3}$ They strategically organized this tribunal so that it appeared not only as a political event but also as a forum for serious reflection on international law.

In this article, we suggest that this approach to the tribunal's organization is linked to the growing role legal action plays in the repertoire of actors engaged in denouncing environmental problems. Several anthropological studies point out that international [p. 192] environmental networks are increasingly using legal action as a weapon to denounce "harmful corporations" (Benson and Kirsch 2010; Dietrich 2013; Kirsch 2003, 2012). In Peter Benson and Stuart Kirsch's words, such corporations are "capitalist enterprises that are predicated on practices that are destructive or harmful to people and the environment" $(2010,421)$. In light of this shift, environmental

\footnotetext{
${ }^{1}$ See, for example, the arguments presented on the Combat Monsanto website, http://combat-monsanto.org/.

2 See "An Open Letter," written by Brian Lowry, Martha Burmaster, Rosalina Syahriar, and Jorge Chepote, of various Monsanto committees, published on the company's site on October 12, 2016, http://monsantoblog.eu/an-open-letter-about-the-monsantotribunal/\#.V_4ZXMB95hE.

${ }^{3}$ Excerpts from main organizer Marie-Monique Robin's speech at the International Monsanto Tribunal press conference, December 3, 2015 at https://vimeo.com/149612020.
} 
tribunals of opinion are gaining importance. Activists invest in them as spaces not only to criticize the political order but also to legitimate contested legal concepts and prepare for more formal legal actions. The International Monsanto Tribunal illustrates this shift. Several legal professionals participated extensively in its organization. They considered it as a place where they could promote a legal concept (ecocide), advocate for its use in future legal proceedings, and, more generally, consolidate the legal expert networks in which they are involved. In view of these objectives, it was important for those organizers to demonstrate the tribunal's legitimacy.

Assessing the legitimacy of opinion tribunals is a complex issue (Klinghoffer and Klinghoffer 2002; Moita 2015; Simm and Byrnes 2014). In this article, we do not adopt a normative perspective. Instead, we focus on the many efforts made by the tribunal's organizers to increase its legitimacy. Anthropologists investigating international criminal courts have shown that the legitimacy of these courts is a construct, determined by the selection process and use of expert witnesses (Wilson 2016), and by the architecture of the buildings in which justice is served and which temporally organize hearings (Eltringham 2012). In the same vein, we analyze how the International Monsanto Tribunal's organizers set rules regarding the selection of judges, the hearing of witnesses, and the set-up of the spatial organization, all of which aimed at strengthening the tribunal's legitimacy and show that some rules had to be negotiated among the different participants of the tribunal. This de- tailed analysis of the work that NGOs and environmental activists do to legitimize opinion tribunals enriches our understanding of their relationship to the law as a means of political action. It documents their subjective attachment to international legal institutions, and shows how strategic they are in their attempt to maximize the political effects of tribunals of opinion. Scholars often stress that tribunals have mainly indirect effects. Still, they also insist on their constitutive force, and the impact organizations have on the people who at- tend the tribunals to demand justice for the violence they have suffered (Hugues 2018). Our article encourages scholars to question how understandings of tribunals circulate among specific audiences. Indeed, we show that the efforts made to legitimize the International Monsanto Tribunal were largely aimed at the media and the legal community, and that those efforts did increase the press and academic attention the tribunal received.

This article is based on ethnographic observations of the International Monsanto Tribunal. We attended the tribunal's two-day public hearings in April 2016 in The Hague, listened to the debates, and observed the informal exchanges. To make further sense of this 
event, in 2016 and 2017, we conducted formal interviews, sometimes on a repeated basis, with a dozen tribunal participants, including two judges and organizing committee members. Second, before and after the event, we collected and analyzed the numerous and widely circulating documents distributed by the tribunal's organizers (e.g., films, articles, etc.) in order to legitimize the tribunal and to extend the militant network it embodies. Finally, we relied on informal exchanges with some organizers of the tribunal as part of broader work relations and activism engagement. One caveat to share here is that Christel Cournil, one of the authors of this article, is a law scholar personally involved in legal activism against climate change, and collaborates regularly with members of the tribunal's organizing committee. However, her various commitments gave us access to places in which the International Monsanto Tribunal was discussed by activists and legal scholars (e.g., meetings, seminars). By following this tribunal in these other arenas of legal [p. 193] discussion, which were often less openly political, we gained a richer understanding of how organizers conceive of the role tribunals play.

\section{Informal Protest Tribunals: An Emerging Repertoire of Action to Denounce Harmful Corporations}

Organizing "trial" type events to attack the political and legal order emerged as a repertoire of action in international civil society during the twentieth century (Blaser 1992; Klinghoffer and Klinghoffer 2002; Simm and Byrnes 2014, 2018). Initially mobilized in the defense of civil, political, and social rights, NGOs engaged in environmental causes now use this type of action because they see tribunals as a way to denounce environmental problems. In a context of increasing use of legal action to influence environmental laws and policies, these tribunals are also places in which activists can denounce the nonapplication of the law and prepare legal proceedings.

\section{Holding Trials to Modify the Legal Order}

During the twentieth century, many political activists organized events that consisted of holding trials outside the formal framework of the state and international organizations. The most cited of these is the people's tribunal created by Bertrand Russell and Jean-Paul Sartre to judge United States crimes in Vietnam; and, more widely, to 
denounce states' monopolies of justice and to work toward the creation of a universally competent tribunal to sanction the most serious state violations of human rights (Zunino 2016). The Permanent Peoples' Tribunal (PPT), ${ }^{4}$ set up in Italy in 1979 in the wake of this first initiative, solidified the tribunal as a mode of grassroots justice (Jouve 1981). Indeed, the PPT was presented as an independent body whose vocation, unlimited in time and space, was to rule on "any serious and systematic violation of peoples' rights, whether committed by states, by authorities other than states, or by private groups or organizations." 5 Since its creation, and thanks to the efforts of an international network of intellectuals, public figures, and experts in legal and other fields, the PPT has held fortyfour sessions during which violations of civil, economic, political, and social rights of individuals, groups, and entire populations from all over the world have been denounced.

Tribunals of opinion initiated by citizens or activist organizations at the margins of institutional justice have multiplied over the last fifty years (Moita 2015). These have been highly diverse in their objectives, organization, and links with existing judicial systems and jurisdictional orders. Some have investigated the use of force in conflicts (Borowiak 2008; Byrnes and Simm 2013); others, the violation of certain minorities' rights, such as the people's tribunal on the state's violation of Roma children's rights in Paris in 2015. While some have been set up alongside existing formal procedures, others have sought to compensate for the lack of legal means on certain issues or to advocate for human rights (Klinghoffer and Klinghoffer 2002). Despite their diversity, which is also reflected in the variations in terms used to describe them-peoples' tribunals, tribunals of opinion, civil society tribunals, and, more recently, tribunals of conscience-these initiatives have instituted the practice of a deliberative justice as a possible form of action in transnational human rights defense networks' repertoire of action. Since the 1990s, environmental NGOs increasingly use this form of action to address environmental issues. In part, their interest in tribunals of opinion must be understood as a consequence of the increasing role legal action plays in environmental activism.

\section{[p. 194] Environmentalism in Tribunals of Opinion}

\footnotetext{
4 The PPT was the initiative of Lelio Basso, an Italian senator, lawyer, and theoretician. One specificity was to foreground the Universal Declaration of the Rights of Peoples, adopted in Algiers in 1973.

${ }^{5}$ See http://permanentpeoplestribunal.org/mandate-and-functions/?lang en.
} 
Over the last several decades, environmental activists have invested more of their resources and expertise in legal actions to influence environmental policies, a trend that Vanhala (2012) described as a "global judicialization" of environmental disputes. Through legal actions, they have advocated for the "greening" of regional judicial human rights bodies (Cournil 2016), and increasingly used the language of human rights and environmental protection in their political struggle (Conca 2015; Woods 2010). Along with increasing their use of legal action, environmental activists and organizations have invested resources in setting up tribunals of opinion. They see tribunals as a way of denouncing environmental problems at an international level, and as a means of communicating to the media complex transnational issues in a way that is particularly clear and comprehensible. They also consider tribunals of opinion as places in which they can promote new legal concepts and discuss future legal proceedings.

This growing interest has resulted in the multiplication of tribunals of opinion focused on environmental issues. From 1992 to the writing of this article, the PPT has, for example, held eight sessions related to socio-environmental issues; the most recent, in 2017, concerned the extractive industries and land grab in South Africa. All these sessions have highlighted the irresponsibility of states, certain emblematic companies, and public-private consortia in environmental terms. However, it is outside the framework of the PPT that many other initiatives have been organized on myriad environmental themes. In 2009-2010, for example, Oxfam established "climate tribunals" in thirty-six countries. ${ }^{6}$ Another recent example is the organization of the International Rights of Nature by the Global Alliance for the Rights of Nature. ${ }^{7}$ Its four sessions, held in 2014, along with the Conference of the Parties on climate, raised subjects as diverse as the climatic impact of exploiting fossil energies, the damage caused by mega-dams in Amazonia, and the financialization of nature (Maloney 2016). Activists have also set up permanent tribunals focused on environmental issues, including the Indian Independent People's Tribunal and the Latin-American Water

\footnotetext{
${ }^{6}$ See "Bangladesh Climate Tribunal: Taking Action Against Climate Change," published December 17, 2010, on the Oxfam International website, https://www.oxfam.org/en/tags/climate-tribunal.

7 Global Alliance for the Rights of Nature, https://therightsofnature.org/.
} 
Tribunal. ${ }^{8}$ The latter tribunal has been well studied and is considered as having succeeded in constituting particularly rich spaces for the development of civil justice (Giupponi 2016; Maganda 2009). The International Monsanto Tribunal is yet another example of the growing interest environmental organizations have for opinion tribunals.

\section{The International Monsanto Tribunal: Publicizing Environmental Wrongdoings, Promoting Legal Concepts}

The International Monsanto Tribunal's organizers pursued two main objectives: publicize broad criticism against harmful corporations, and prepare legal actions against those companies by promoting legal concepts and networks. By focusing on the multiple negotiations that accompanied its creation, we show how this second objective gained importance, and was put forward by activists who are legal experts.

\section{The International Monsanto Tribunal: Context}

The International Monsanto Tribunal hearings were held on October 15 and 16, 2016, in The Hague, a city strategically chosen because it is where the International Criminal Court (ICC) has its own buildings. The tribunal took place in a large auditorium at the Institute of Social Sciences. Five judges sat on a platform facing the audience. Over these two days, thirty witnesses and experts (researchers, scientists, lawyers) from several continents followed one another, sitting at a desk to testify and express their grievances against [p. 195] the corporation. Off to the side, sitting at a table, two legal clerks recorded answers to the judges' questions. The hearing sessions were punctuated by breaks during which the judges isolated themselves in a room to which only they and the clerks had access. The audience was large and attentive. Composed mainly of activists, journalists, legal students, and scholars, they could circulate between the space of the tribunal itself and another space of debates, known as the People's Assembly. Located two kilometers away at the

\footnotetext{
8 Indian People's Tribunal, "Articles in the Environment Category" at http://www. iptindia.org/category/environment/; and Tribunal Latinoamericano del Agua at http://tragua.com/.
} 
People's Assembly, public participants in the tribunal could share their experiences and debate with staff from numerous NGOs involved in the defense of the environment and human rights in a much less technical and solemn way.

The court's hearings were organized according to six themes: right to a healthy environment, right to health, right to food, right to freedom of expression and academic research, complicity in war crimes, and ecocide crime. To guide judges to produce a legal opinion on these topics, the organizers worked for several months to draft terms of reference clarifying the legal framework and, with the help of law students, to prepare legal memos on each of the topics. The tribunal's advisory opinion was initially scheduled for December 2016, but was delivered on April 18, 2017, at a press conference held in The Hague. It was then widely distributed in the press and media. The organizers of the International Monsanto Tribunal paid considerable attention to the publicity of the event and its media coverage. The two days of the court hearing were broadcast live on the Internet; the preparatory documents were also available online; and a journalist, one of the main organizers of the event, made two documentary films about it.

\section{From Impossible Trial to Media Event}

The organization of the tribunal took several years. Its genesis dates back to the mobilization of activists-members of the Longo Mai, a European network of self-run farm and artisanal cooperatives-and of the European Civic Forum-an international solidarity network involved in agriculture and migration. ${ }^{9}$ These activists joined communities of Colombian farmers in their opposition to the 2010 United States-Colombia Free Trade Agreement. Activists notably denounced its impact on the farmers' right to use their own seeds. On this occasion, some of the activists carried out in-depth research into Monsanto, one of the companies most active in lobbying to limit the conditions in which farmers could use their seeds, in Colombia and elsewhere (Gutierrez Escobar and Fitting 2016). In particular, they examined the possibility of requesting that the ICC open an investigation into the company. They realized, however, that this undertaking was fruitless. Monsanto's headquarters are based in the United States, a country that has not ratified the Rome Statute of the ICC. It is also not in the ICC's jurisdiction to investigate company leaders outside cases of armed conflict. The organizers imagined an event, initially hazily defined in its form, that would judge, according

\footnotetext{
${ }^{9}$ European Civic Forum, "Our Missions," http://civic-forum.eu/civic-forum/missions.
} 
to a main organizer from Longo Mai, "the multinational's crimes against humanity and against the environment." 10 Considering that such a project was too ambitious for the Longo Mai communities alone, these activists mobilized several figures already involved in denouncing intensive farming in general and Monsanto's practices in particular.

In 2014, Longo Mai gained the support of investigative journalist Marie-Monique Robin. In 2008, Robin had released a film and published a widely referenced book that environ- mental activists used to denounce Monsanto's practices (Robin 2008). Having agreed to become the initiative's official supporter, Robin put her reputation and network at the group's service; and, together with the Longo Mai activists, they came up with the idea of a "civil society tribunal." Robin's international reputation and contacts enabled her to set [p.196] up an organizing committee composed of important figures in the defense of human rights and the challenges to industrial agriculture that were likely to interest the media. However, her engagement had an additional impact on the nature of the project. Robin had been investigating the health and environmental impact of glyphosate, a substance contained in the main herbicide commercialized by Monsanto. She imagined organizing an event to incriminate the company that could serve as the central element of the film she was making of her investigation. As a result, she pushed for the organization of a large-scale tribunal, a media event likely to give striking images. She was active in locating a significant budget that would fund the travel for interviewees from around the world, so as to be able to film them as witnesses during the tribunal. The tribunal's final budget stood at nearly four hundred thousand euros, which is exceptional for a tribunal of opinion. She was also influential in the tribunal's focus on one firm, Monsanto, whose practices were presented as the absolute worst among multinational firms.

Robin's work was thus a key element in a strategy to stage the tribunal as a media event. Such work is central for organizers of most tribunals of opinion, who generally consider tribunals as forums for publicizing political issues. In the Monsanto case, organizers also aimed for the tribunal to advance legal debate on the practices of such firms.

The Involvement of Transnational Legal Experts

\footnotetext{
${ }^{10}$ Authors' translation, from an interview in the Swiss weekly L'Evénement Syndical, and reproduced on the website dedicated to the Tribunal: http://fr.monsantotribunal.
} 
The Longo Mai activists also obtained the support of Olivier de Schutter, a Belgian legal scholar specializing in human rights and, at the time, the special rapporteur on food rights to the United Nations Human Rights Council. He knew Robin, having worked with her to recruit other legal experts to the organizing committee, including lawyers or legal scholars who specialize in international environmental law. Notably, they recruited Corinne Lepage, a lawyer and a former French Environment minister; Valerie Cabanes, a French legal expert, activist, and founder of End Ecocide on Earth; and Emilie Gaillard, a legal scholar who specializes in the rights of future generations.

These recruitments influenced the organization of the International Monsanto Tribunal. They did not content themselves with simply organizing a tribunal of opinion; they also promoted, as one of the organizers told us, the idea that this tribunal must be "something other than the umpteenth anti-Monsanto, or antipesticides, or anti-GMO manifestation." This statement reflects, in part, a discouragement vis-a'-vis the efficiency of classical modes of political protest. Indeed, some of the recruits have been involved in environmental organizations for years, and have participated in several actions (e.g., demonstrations, petitions, tribunals) to denounce corporations' harmful practices, but with limited perceived results. Above all, this statement illustrates the hope among legal experts that legal mobilization could improve the efficacy of political protests. Several experts were involved in the preparation of legal proceedings on environmental issues, and they did not consider this tribunal as an arena of mobilization clearly separated from those other legal actions. On the contrary, they promoted the idea that this opinion tribunal should be organized so as to produce legal arguments and discourses likely to support traditional legal proceedings and get the attention of other legal experts.

They suggested, for instance, that the main outcome of the tribunal should be the production of a legal document sufficiently precise and technical so as to be useful for other legal experts in their work. Specifically, they suggested that the tribunal should produce an advisory opinion, along the lines of those issued by the International Court of Justice (ICJ), the principal judicial organ of the United Nations in settling legal disputes among member-states. Taking the ICJ advisory opinion as a model had several advantages for the [p. 197] tribunal's organizers. The ICJ's advisory opinions are well-known types of legal productions, described as influential in the development of the international law (Mayr and Mayr Singer 2016). Using them as a model also allowed them, as one of the tribunal organizers explicitly said in a preparatory meeting, not to "follow 
strictly the rules of civil procedure, or, even more difficult to do, the rules of criminal procedures, that would require the rights of defense to be better safeguarded."11 To maximize the chance that the legal discussions held during the event would interest legal scholars and lawyers, members of the organizing committee defined explicit and limited legal terms of reference-the United Nations guidelines on companies and human rights, and the International Covenant on Economic, Social and Cultural Rights-to frame the debates on Monsanto's wrongdoings.

Moreover, some of the legal experts involved in the organization of the tribunal used their participation to promote specific legal concepts. In particular, members of the End Ecocide on Earth network promoted the concept of ecocide. ${ }^{12}$ Ecocide can be broadly defined as the widespread damage or destruction that would have the effect of seriously and lastingly altering global communities or ecological systems. End Ecocide on Earth is one of the many organizations that have promoted this concept, which has been in use since the 1970s (Greene 2019). This network calls for a precise definition of this crime and for its introduction as the fifth crime in the statutes of the ICC (along with the crime against humanity, the crime of genocide, war crimes, and the crime of aggression). Members of End Ecocide on Earth consider that such an introduction would not only create new legal venues but also modify people's language and perception toward a less anthropocentric approach to the environment. Cabanes, the aforementioned spokesperson for the End Ecocide on Earth network developed this idea extensively in her book (2016). In 2014, the network presented 170,000 signatures to the European Parliament in support of a European Union law against ecocide. Shortly after, some of this network's members considered the International Monsanto Tribunal as an event in which they could continue the promotion of this legal concept. This promotion was discussed by the members of the organizing committee. During our research, we were told that some members were concerned about the overly prospective and nonconsensual character of this notion from a doctrinal point of view, and about the risk that it might overshadow the effects of Monsanto's practices on human health by focusing attention solely on environmental effects. Nevertheless, the numerous promoters of the concept did convince the less enthusiastic members of the committee to make it the central objective. Hence, the first press conference of the International

\footnotetext{
${ }^{11}$ This assertion is heard in Le Tribunal International Monsanto, Le Making of, by MarieMonique Robin, uploaded June 5, 2018, https://vimeo.com/273597550.

12 End Ecocide on Earth, https://www.endecocide.org/.
} 
Monsanto Tribunal was held parallel to another event focusing on ecocide (a session of the International Rights of Nature Tribunal, held in Paris in December 2015). It was also decided that members of the End Ecocide on Earth network would testify before the tribunal judges, and that the latter would be asked to hand down an opinion on the expediency of including the crime of ecocide in international law.

The participation of professional legal experts generally instituted the tribunal as a space for reflection on the means of action available in positive international law. Inversely, tribunal organizers did not frame it as a forum for criticizing the universalist claims of international criminal law and international human rights law, which is the critique at the heart of certain tribunals of opinion that, not without ambiguity, claim the heritage of the Russell project (Icaza 2015; Merry 1996; Zunino 2016).

This legalist approach was not the project of the activists responsible for initiating the tribunal; rather, it imposed itself with the growing involvement of legal experts from transnational networks. They saw an interest in organizing the International Monsanto Tribunal "to go further than simple moral condemnation," which was a comment made after one of the hearings by an activist involved in setting up the tribunal. They were using [p. 198] the tribunal to develop legal concepts and to give visibility to their own approaches to these concepts, rather than those promoted by other legal experts (Higgins, Short, and South 2013; Lay et al. 2015; Neyret 2014). As one organizer said:

Because of her media visibility, some people in the organizing committee [of the International Monsanto Tribunal] would like Polly Higgins to be an official supporter of the tribunal. ${ }^{13}$ I find her definition [of ecocide] not enough scientifically grounded though. It is far too complicated for a prosecutor to rely on it. This is my personal opinion. So I do not know what will happen. So far as I am one of the founders of the tribunal, I have imposed the use of our definition. ${ }^{14}$

This excerpt demonstrates how important it was for legal experts involved in the organization of the tribunal to reflect on the impact the

\footnotetext{
${ }^{13}$ A former lawyer promoting a competing definition of ecocide, Higgins organized a mock trial on ecocide in 2011, which drew the attention of the international media. See http://eradicatingecocide.com/the-law/mock-trial/.

14 Personal interview with an organizer, Paris, May 2016.
} 
opinion tribunal could have on actual legal proceedings. It also shows that the tribunal was a space-among many others (Dezalay 2004) -in which legal experts could come to the fore and make a name for themselves as legitimate players in the reflection on the evolution of international law. With this in mind, they attached specific attention to the issue of the tribunal's legitimacy and to the demonstration of the quality of the legal arguments upon which the legal discussions would be based.

\section{Legitimization: Negotiating the Legitimate Way to Say the Law}

Organizers of the International Monsanto Tribunal wanted to strengthen the credibility and legal legitimacy of the tribunal for both the media and the legal community. They imagined various means to show that the legal debates within the court itself would be based on sound legal reasoning and the judges protected from political pressure. They intended, thus, to perform a distinction between the political and the legal dimensions of the tribunal. In the following section, we describe in detail some of the means they used to do this, and how they insisted on implementation and negotiation, in particular with the judges recruited to produce an advisory opinion.

\section{Constructing the Judges' Independence}

To legitimize the International Monsanto Tribunal, its organizers mainly referred to an idea that is commonly shared and diffused in official international courts (Mackenzie and Sands 2003); namely, that a court's legitimacy depends largely on its ability to guarantee the independence of the judges. To attest to this independence, the organizers foregrounded the quality of the judges they had chosen, and the autonomy those judges had in writing their legal advisory opinion. The tribunal organizers repeated the quality of the judges in the press, on the event's website, in informal exchanges among themselves, and with us as researchers. They recognized that the choice of judges would be the result of a series of arbitrations during which they had to contend with the availability of those contacted and to resolve any constraints. As one organizer highlighted to us, one constraint was finding people whose professional engagements did not make them appear biased in attacking Monsanto: 
We might easily be attacked over the militant nature of the organizing com- mittee, but the judges, though, they aren't specifically anti-Monsanto judges. They were indeed not chosen at random. They were not chosen according to a belonging. They were chosen among those who accepted, they were chosen [p. 199] among those who have experience in the international courts, and l'd say a little cynically, among those who didn't fall "sick [i.e. physically able to move despite their age or health problems]."

Another constraint was finding judges who would agree to put their reputations on the line while participating in the tribunal. One result was that several who did agree to sit were retired experts. The organizers nonetheless expressed their satisfaction with how these arbitrations worked out. In particular, they pointed out three implicitly hierarchical points that guaranteed the quality of the judges: the five people who agreed to fulfill the role of judge were all legal professionals who had previously worked for official international judicial organizations, and they comprised a relatively balanced group in terms of geographic origin and gender. These criteria demonstrate a certain conception of their legitimacy to speak the law. Those considered legitimate were not lay citizens united in a people's jury or intellectuals, but were truly judges who met criteria akin to those required by many existing courts of justice.

Beyond the selection of judges recognized for their legal expertise, the organizers sought to legitimize the court by adopting procedures to show that the judges were able to prepare their deliberations without pressure from the organizing committee. For example, the press, witnesses, and tribunal's organizers were forbidden access to the deliberation room and judges' lounge. Moreover, the organizers committed to not partake in the long deliberation work and preparation of the judges' final statement, and they limited their exchanges with the judges to a strict minimum. These rules did not prevent any influence on the work of judges. In reality, the organizers did partly frame this work by formatting, for instance, the legal documents and written testimony on which the judges had to rely to produce a legal opinion. To understand the limits of this influence, and, more generally, to understand how judges also participated in the production of the International Monsanto Tribunal's legitimacy, it is important not to focus solely on the organizers' perspective but to shift the focus on the judges' work.

15 Personal interview with an organizer, Paris, September 2016. 
The judges met for the first time in October 2016, when they arrived in The Hague the day before the hearing. They familiarized themselves with numerous elements prepared by the tribunal's organizers: the legal memos designed to help them in their reflection, prepared for months by students supervised by members of the organizing committee; the list of witnesses and experts who were to testify, and their written contributions; the rooms where they were to preside or deliberate; the nomination of the court clerks who would directly contribute to drafting the final advisory legal opinion, and so forth. The judges relied on their professional authority and the independence granted to them by the organizers to negotiate some of those elements, and to promote their conception of a legitimate way to interpret the law in a tribunal of opinion.

This contribution of the judges to the tribunal's legitimacy is well illustrated by their negotiations over the so-called terms of reference. These terms invoked certain human rights-for example, the right to food, the right to enjoy the best state of physical and mental health, the right to freedom to scientific researchcharacterized by their plasticity and flexibility, and thus their "ability to link the aspirations of actors situated in very different cultural, political and social contexts" (Pieret 2015, 75). These terms of reference framed the judges' debates and echoed strongly in the advisory legal opinion that they handed down. ${ }^{16}$ The terms were nonetheless partly redefined by the judges over the course of their work and exchanges. From the start of the hearings, the judges notably eliminated the question of evaluating Monsanto's culpability from the tribunal's objectives. It should be noted that this did not stop the media from sometimes presenting the advisory opinion [p. 200] as a judgment of the culpability of the firm, as we demonstrate further on. Indeed, as one of the judges insisted during an interview, although they were expected to produce an advisory legal opinion, judges were presented with initial terms of reference whose wording referred too directly to Monsanto's civil or criminal liability issues. They quickly considered that they did not have the means to establish this culpability, and that, in seeking to establish it, they would overstep the role of a tribunal of opinion:

When we convened the day before the first hearing, our first concern was to rewrite the terms of reference, because they

\footnotetext{
16 The advisory opinion cited the International Covenant on Civil and Political Rights of December 16, 1966; the International Covenant on Economic, Social and Cultural Rights of December 16, 1966; the Convention on the Rights of the Child of November 20, 1989; and the Convention on the Elimination of All Forms of Discrimination Against Women of December 18, 1979.
} 
had been drawn up too . . . "Is Monsanto guilty of," which we couldn't commit to. We absolutely had

to avoid falling into the trap of it being said that we were a "fake court" attempting to establish civil and criminal responsibility. So, we rewrote that, asking whether, based on the texts, testimonies, and documents at our disposal, Monsanto's activities were in conformity with the texts of international law. ${ }^{17}$

In the deliberations that followed the hearings, the judges also threw out the organizing committee's question concerning Monsanto's war crimes, determining that they did not have enough elements to pronounce on a subject that was so explicitly the domain of already existing international legal institutions. In the end, the opinion they produced was based on the terms of reference proposed by the organizers, but which offered a more technical and nuanced critique of the accusations they brought forth.

In addition to the terms of reference, the judges also negotiated more informal elements of the framework proposed to them. For example, during their first meeting, the judges explainedto certain organizers' regret-that they would not wear legal robes during the hearings to prevent confusion between the International Monsanto Tribunal and official international courts, and so not as to appear, as one judge described, "ridiculous." These exchanges are not insignificant. Clothing prescriptions and choices reveal and craft the subjective relations people in courts have to law (Cabatingan 2018). By proposing that judges wear black robes, the organizers of the tribunal wanted to show the general public and the media how close it was to a real court of justice. By refusing, the judges reasserted the boundaries between this tribunal and existing legal institutions, legitimating both, and preserving their own professional credibility. Regardless of the judicial uniform, the framework put in place by the tribunal's organizers to demonstrate the independence of judges had effects. The judges, relying on their independence, redefined the nature of the tribunal, stressing that its legitimacy depended on the acknowledgment that it is not a "true" court.

\section{Righteous Witnesses Versus an Absent Defense}

In addition to establishing the judges' independence, the organizers sought to increase the tribunal's legitimacy by insisting that they were

17 Personal interview with a judge, November 2017. 
committed to establishing rules that guaranteed a fair procedure, notably with regard to the hearing of witnesses and the defense. Public testimony is, indeed, one of the characteristics common to all tribunals of opinion, and their credibility is built partly on how these testimonies are organized. A prime characteristic of this tribunal was that the organizers had split the testimonial space into two. One space was the tribunal itself, to which people were invited to testify before the judges in their quality of legal expert, witness, or victim of Monsanto. The other space was the previously mentioned People's Assembly space, in which all the members of organizations close to the organizing committee were, for the two days duration of the tribunal, able to speak [p. 201] out in a less personal capacity and in the name of their organizations. This separation between a legal space and an overtly militant space was created to reinforce the legitimacy of the tribunal demarcating political from the legal, and thus to guarantee the appearance of an independent tribunal. The distance between the two spaces did not prevent forms of circulation: the witnesses, members of the public, and journalists were able to frequent the People's Assembly during the event. This separation had several effects.

First, it helped structure the articulation between the two roles with which witnesses are often simultaneously invested in tribunals of opinion: on the one hand, that of victims expected to share with the public their sufferings; on the other hand, that of experts who are expected to draw on their experiences to construct critiques of the unequal structures of power..$^{18}$ For the organizers, it was important that the invited witnesses focus on the first role in the scope of the tribunal:

The same difficulties always arise in a trial. Will the witnesses understand what is expected of them? At first, one of the witnesses wrote us a thing in which he responded to the judges' six questions. He wrote: 'On this question, I think that . . . , because ..., etc., Monsanto is guilty of damage to human health." So, we had to tell him that what we were interested in, rather, was his experience.

...

We want people to speak about themselves, not their opinion on the law, but what they've seen, what they've

\footnotetext{
18 The difficulty of articulating these two roles was a concern in other tribunals, such as the Waitangi Tribunal, a space of postcolonial justice analyzed by Fiona McCormack (2016). She notably highlights how the Maori victims summoned to the tribunal to convey their personal experiences produced intimate discourses that tended to mask the structural and historical reasons for their sufferings.
} 
suffered. I can already see that some will present themselves saying: "I represent the farmers' union," and that's exactly what we want to avoid. ${ }^{19}$

The separation of the spaces facilitated this goal as did organizers' requests that witnesses adjust their wording. These adjustments were far from systematic, however, and no attention was drawn to this activity for fear of throwing suspicion on the credibility and authenticity of the testimonies.

Second, the separation between the People's Assembly and the tribunal shaped the judges' work. During their first work meetings, they agreed on the principles that they would not go to the People's Assembly and would not have any exchanges with the tribunal witnesses outside their hearings. This second rule occasionally incurred minor infringements. For example, as the hearings went on, we observed during hearing breaks more and more informal, and at times even warm, exchanges between witnesses and certain judges. This rule, however, had non-negligible effects. As one judge explained, this separation rule helped them to don their role of impartial judge, not only so others would believe it but also so that they believe it themselves; thus, they were engaging in an intellectual process similar to that practiced in professional spaces of judicial expertise:

It is important to respect the idea of an independent and impartial judge, not only to be one, but also to give the impression of being one. So, it would have been illogical to mix or share meals with the organizing committee; we avoided this as much as possible. And dining with the witnesses. We didn't; we stayed among ourselves, and that's an important point, because otherwise, it would of course be said that we were influenced. During an investigation, you don't dine with the parties involved. ${ }^{20}$

Another characteristic of the organization of the public testimonies was that there was no opposing debate. Monsanto chose not to defend itself during the two days in which its activities were assessed, and the judges did not organize any cross-examination of the witnesses. This characteristic is shared by many tribunals of opinion. It prevented the [p.202] tribunal from being a space of

\footnotetext{
19 Personal interview with an organizer, Paris, September 2016.

20 Personal interview with a judge, Paris, November 2017.
} 
mediation (contrary, for example, to certain sessions of the LatinAmerican Water Tribunal [Giupponi 2016]) and created a somewhat ambiguous effect on its legitimacy. The lack of representation of defense arguments prevented the accusations prepared by the organizers and voiced by the witnesses from being cross-examined and challenged. However, the lack of adversarial debate risked discrediting any decisions by turning it into a political tribunal. To avoid this, the organizers insisted that, in accordance with the general principles of civil procedure, they had repeatedly invited Monsanto to present its arguments before the judges. They demonstrated that it was the multinational that had refused to participate in an attempt to discredit the event.

For the organizers, the invitations addressed to the company were proof that they had respected the defense's rights. For the judges, however, this created an uncomfortable situation. They discussed it at length: Should Monsanto have been attributed a duty defense counsel? How were they to administer the law when it was not materially or temporally possible to verify testimonies? To resolve these difficulties, they "assumed to be true" the testimonies and expertise that they heard. This formula, as one judge told us, was "chosen very specifically" and was essential to their work. Indeed, the judges invented this construct to defend a judicially autonomous space in the otherwise political event that was the tribunal. This solution was implicitly based on a distinction between facts and law, widely discussed in legal anthropology (see Riles 2000). The judges limited their role to interpreting the law, and restrained themselves from questioning the facts as described by witnesses and experts. However, to appear legitimate, they relied on representations of reality-memos, expert reports, and so on-that they received from the organizers. This, of course, influenced their work.

Some observers opined that by insisting on the legitimacy of the International Monsanto Tribunal and by organizing it as a "true" tribunal, its organizers risked confusing the witnesses (Goedert 2017). Did the witnesses understand that the tribunal was not official? Did the tribunal risk, at best, confusing them, and, at worst, disappointing them? It is not easy to answer these questions, given the diversity of the witnesses and their experiences of the tribunal. The witnesses we met, however, never thought that they were testifying before a court that would deliver a legal ruling that would directly modify Monsanto's practices or enable them, as victims, to obtain effective reparation. Most were already engaged in civil or criminal procedures in their home countries, in which they faced extremely demanding testimonial obligations that bore no comparison with what they experienced at the International 
Monsanto Tribunal. This was true, for example, of the French farmer Paul François, an activist whose judicial path has been followed for several years by one of this article's authors. His progressive involvement over the last ten or so years in denouncing the impact of pesticides on the health of farm workers is closely linked to his experience of the civil judicial procedure that he filed against Monsanto following acute intoxication from a herbicide commercialized by the company (Jouzel and Prete 2015). For him, there was no confusion between his testimony at The Hague, where he came to share his experience with others and to give international visibility to the association he created in France and to the many hearings he-often painfully_took part in during his civil procedure. Rather than causing confusion, the organizers' efforts to legitimize the tribunal reinforced the other well-known effects of tribunals of opinion: namely, the legitimization that comes from pooling complaints and experiences of suffering (Lambert-Abdelgawad 2006; Malviya and Canali forthcoming). [p. 203]

\section{The Effects of Legitimization: Media and Academic Visibility}

The organizers' efforts to legitimize the tribunal were part of a successful strategy to increase the attention it would receive both in the media and in the legal community. The tribunal received significant media coverage because it was organized from the outset as a visual event, intended to circulate widely in the form of films, and because it could be considered by some journalists as a credible space of legal debate. It was also largely followed in academic circles by both those who contributed to its organization and by those who did not.

\section{Monsanto Found Guilty: Circulation of an Advisory Legal Opinion in the Media}

As noted, organizers conceived of the tribunal as a media event from the start, and they took several steps to ensure media coverage. On December 3, 2015, a press conference was held in Paris to announce the tribunal's creation during the United Nations Climate Change Conference, and the third session of the International Rights of Nature Tribunal, in which several of the tribunal organizers actively participated. During the tribunal, the hearings were live-streamed and widely shared on social media, and many journalists were invited to 
participate in the event. In April 2017, the organizers held another press conference to present the judges' advisory opinion. In fall 2017, the release of Marie- Monique Robin's previously mentioned film, as well as a book entitled Roundup Facing Its Judges, reinvigorated media attention. Her film is mainly alternating footage of certain witnesses' hearings in The Hague-especially those most directly impacted by the potential effects of glyphosate on human health-and more intimate interview footage of the same witnesses in their homes. This film gave victims the chance to speak out. It was also an occasion to recall the very specific legitimacy of the tribunal. Indeed, the voiceover in the film reminds the viewer, on several occasions, that the tribunal was "presided over by real judges" with undeniable legal expertise.

The tribunal's organizers' regular emphasis of their legitimacy and credibility contributed, along with other elements, to increased media coverage. It gave journalists - notably environmental journalists, who are often in the minority in their editorial teams - arguments to convince their employers that they were going to follow a sufficiently serious event (Comby 2009). They could, for example, insist that the tribunal concerned an environmental issue and a highly considered international affairs topic, as it was in a space to debate international law beyond just the Monsanto example. Journalists could claim that they would provide balanced reporting and respect their profession's prevailing norms of neutrality (Tandoc and Takahashi 2016), and that the tribunal involved leading legal experts. For these reasons, the International Monsanto Tribunal facilitated its own media coverage. It was, for example, particularly well covered by the French print media and, albeit to a lesser degree, by the international press. For example, articles covering the tribunal appeared in France's Le Monde (2016), Switzerland's Le Temps (2016), Germany's the Frankfurter Allgemeinezeitung (2016) and the Tageszeitung (2016), England's The Guardian (2016), and Argentina's El argentino (2016). Nevertheless, the press at times created imprecise presentations of the trial. Indeed, while the articles relayed the judges' opinion and included the mock nature of the trial and the advisory nature of their legal opinion, some article titles may have given the impression that Monsanto had been tried by an officially recognized international court. For example, an article in the leading French newspaper Le Monde, on the day the opinion was handed down, published the following headline: "Monsanto Tribunal: The American company found guilty of violating human rights" (Le Monde, 2017). This headline was denounced by some journalists known for their support [p. 204] to intensive farming as unacceptable confusion (see Senapathy 2015). Paradoxically, by criticizing the media coverage 
and insisting that it tended to mask the political nature of the tribunal, these journalists boosted the Tribunal's media coverage. Tribunals of opinion rarely attract much media attention. They generally garner even less attention among legal professionals, and legal scholars in particular. In this respect, the International Monsanto Tribunal appears to be an exception.

\section{The Doctrinal Effects of a Tribunal: From Networks to Legal Commentaries}

The tribunal's organization also allowed legal experts to meet legal professionals from other countries, notably the victims' defense lawyers and experts actively engaged in denouncing the environmental crimes committed by multinationals. Ultimately, it allowed them to develop further the transnational activist networks to which they belong. For example, one of the lawyers actively involved in the organization of the tribunal recently set up an NGO to systematically gather information on all legal action taken around the world concerning pesticide intoxication. The executive board of this NGO mostly comprises participants from the International Monsanto Tribunal, some of whom met for the first time at The Hague. ${ }^{21}$ In an informal exchange we had on the train when leaving the day after the tribunal ended, this lawyer shared with us her satisfaction: the tribunal was a success not only because many people attended to the sessions but also, above all, because it had appeared credible. She was confident it would contribute to the promotion of ecocide and, even indirectly, stimulate the initiation of legal proceedings against harmful companies.

Surprisingly, and indirectly, the tribunal attracted the attention of legal scholars in less overtly political spaces. In France alone, its objectives and advisory legal opinion have been commented on and discussed in an array of university seminars and academic articles (e.g., Gaillard 2017; Le Bris 2017; Poissonnier 2017). The academic world's interest in the tribunal-of which this article is an illustration, especially given that one of its authors is a legal scholar-is, on two counts, a result of the organizers' legitimization efforts. First, this effort consisted in directly organizing academic events in connection with the tribunal to make it more visible. These were opportunities to disseminate certain legal arguments among expert audiences who were less familiar with them, notably arguments on ecocide. Second, the event's credibility, which stemmed from the reputation of certain

21 Justice Pesticides, https://www.justicepesticides.org/en/. 
members of the organizing committee and from the quality of the judges who drew up the advisory legal opinion, guaranteed the tribunal a form of respectability among certain legal scholars. It rendered the advisory opinion worth commenting upon in the framework of wider-and highly intense-doctrinal debates on multinational companies' responsibilities, and on the articulation between human rights and environmental protection.

It is impossible to precisely evaluate the doctrinal impact of the advisory legal opinion handed down by the tribunal, given that it was inscribed in the continuity of a multitude of other initiatives. Nevertheless, the foregrounding of this impact emerges as both a condition and a consequence of the legitimization of the International Monsanto Tribunal. It was highlighted by both the organizers and the judges, for whom it constituted a form of recognition and a motivating factor of their engagement.

\section{Conclusion}

Recently, individuals accusing Monsanto of being responsible for their poisoning from pesticides obtained favorable court decisions in civil proceedings, in France and in the United States, giving access to valuable internal documents to the opponents of the firm and other harmful corporations. ${ }^{22}$ Some of the people engaged in those legal proceedings [p. 205] were present at the International Monsanto Tribunal in 2016. In this article, we suggest that opinion tribunals and "real" tribunals should not be regarded as separate arenas of mobilization. Indeed, as legal action plays a growing role in the repertoire of action of actors engaged in denouncing environmental problems, legal activists increasingly consider opinion tribunals as venues in which they can develop their professional networks and positions, promote legal concepts, and prepare future traditional legal actions. We stress that, in this context, legitimizing opinion tribunals is important for organizers. To build the legitimacy of the International Monsanto Tribunal, its organizers provided evidence of their ability to uphold principles - for example, the independence of the judgesand legal standards put forward by state-backed international institutions. In these respects, this tribunal could be described as a nonradical form of contestation of the international legal order.

Its organizers staged a classical demarcation: the scenes of legal discussions and political discussions were spatially separated;

\footnotetext{
22 See "Roundup (Glyphosate) Cancer Cases: Key Documents \& Analysis," U.S. Right to Know, https://usrtk.org/pesticides/mdl-monsanto-glyphosate-cancer-case- key-documentsanalysis/.
} 
the relations between the judges and other participants were limited to ensure the independence of the former; and the testimonies of the victims were reformulated using legal terms. Anthropological research insists that this demarcation is always an object of negotiation, even in institutionalized courts of justice. In the context of an ad-hoc tribunal, those negotiations are numerous. In particular, we described how the legal professionals who organized the International Monsanto Tribunal negotiated with many participantsfrom the less legally oriented members of the organizing committee to the well-experienced judges - to keep this demarcation credible and, eventually, to attract both the attention of the media and other legal professionals.

\section{References Cited}

Anonymous, 2016. "Finaliza hoy en La Haya el proceso contra Monsanto," El Argentino, October 16.

https://www.diarioelargentino.com.ar/noticias/168739/Finaliza-hoyen-La-

Haya-el-proceso-contra-Monsanto.

Barroux, Rémi. 2016. "Au 'Tribunal Monsanto', des militants veulent mettre l'environnement au cœur du droit international" Le Monde, $\quad$ October $17 . \quad$ https://www. lemonde.fr/planete/article/2016/10/17/au-tribunal-monsanto-lesjuges-veulent-mettre-Ienvironnement-au-c-ur-du-droitinternational_5014732_3244.html.

2017. "Tribunal Monsanto: la firme américaine reconnue coupable d'atteinte aux droits humains," Le Monde, April 18. https://www.lemonde.fr/planete/article/2017/ 04/18/tribunalmonsanto-la-firme-americaine-reconnue-coupable-d-atteinte-auxdroits-humains_5113185_3244.html.

Benson, Peter, and Stuart Kirsch. 2010. "Capitalism and the Politics of Resignation." Current Anthropology 51 (4): 459-85.

Blaser, Arthur W. 1992. "How to Advance Human Rights Without Really Trying: An Analysis of Nongovernmental Tribunals." Human Rights Quarterly 14: 339-70. 
Borowiak, Craig. 2008. "The World Tribunal on Iraq: Citizens' Tribunals and the Struggle for Accountability." New Political Science 30 (2): 161-86.

Byrnes, Andrew, and Gabrielle Simm. 2013. "Peoples' Tribunals, International Law and the Use of Force." University of New South Wales Law Journal 36:711-44.

2014. 'International Peoples' Tribunals in Asia: Political Theatre, Juridical Farce, or Meaningful Intervention?." Asian Journal of International Law 4.1: 103-124.

eds. 2018. International Peoples' Tribunals: Their Nature, Practice and Significance. Peoples' Tribunals and International Law. Cambridge: Cambridge University Press.

Cabanes, Valérie. 2016. Un nouveau droit pour la Terre: Pour en finir avec l'écocide [A new law for the Earth: Putting an end to ecocide]. Paris: Le Seuil.

Cabatingan, Lee. 2018. "Fashioning the Legal Subject: Popular Justice and Courtroom Attire in the Caribbean." PoLAR: Political and Legal Anthropology Review 41 (S1): 69-84.

Comby, Jean-Baptiste. 2009. "Quand l'environnement devient médiatique': Conditions et effets de l'institutionnalisation d'une spécialité journalistique" [When environment becomes news: Institutionalization of a journalism specialty]. Réseaux 5 (157158): 157-90.

Conca, Ken. 2010. "Environmental Human Rights: Greening "the Dignity and Worth of the Human Person." In Handbook of Global Environmental Politics, edited by Peter Dauvergne, 403-19. Cheltenham, UK: Edward Elgar Publishing.

Cournil, Christel. 2016. "'Verdissement' des systèmes régionaux de protection des droits de l'Homme: circulation et standardisation des normes" [The "greening" of regional human rights protection systems: Norms circulation and standardization]. Journal européen des droits de l'Homme 4 (1): 3-31.

Dezalay, Yves. 2004. "Les courtiers de l'international : Héritiers cosmopolites, mercenaires de l'impérialisme et missionnaires de l'universel" [International brokers: Cosmopolitan heirs, imperialistic 
mercenaries, and universal missionaries]. Actes de la recherche en sciences sociales 151-152 (1): 4-35.

Dietrich, Alexa. S. 2013. The Drug Company Next Door: Pollution, Jobs, and Community Health in Puerto Rico. New York: New York University Press.

Eltringham, Nigel. 2012. "Spectators to the Spectacle of Law: The Formation of a 'Validat- ing Public' at the International Criminal Tribunal for Rwanda." Journal of Anthropology 77 (3): 425-45.

Gaillard, Emilie. 2017. "Le Tribunal international Monsanto, un tribunal d'opinion atypique et audacieux" [The Monsanto international tribunal, comments on an uncommon and bold opinion tribunal]. Revue-Energie-Environnement-Infrastructures 6 (June): 62.

Giupponi, Belén Olmos. 2016. "Transnational Environmental Law and Grass-Root Initiatives: The Case of the Latin American Water Tribunal." Transnational Environmental Law 5 (1): 145-74.

Goedert, Nathalie. 2017. Procès fictif ou justice fiction? [Fictitious trial or fictional justice?]. April 28. http://imaj.hypotheses.org/1751.

Greene, Anastacia. 2019. "The Campaign to Make Ecocide an International Crime: Quixotic Quest or Moral Imperative?" Fordham Environmental Law Review 30 (3).

Grossarth, Von Jan. 2016. "Die Mär von der Vergiftung der Welt," Frankfurter Allgemeinezeitung, September 14. https://www.faz.net/aktuell/wirtschaft/aktivisten- monsanto-unddie-maer-vom-oekozid-14435524.html.

Gutiérrez Escobar, Laura, and Elizabeth Fitting. 2016. "The Red de Semillas Libres: Contesting Biohegemony in Colombia." Journal of Agrarian Change 16 (4): 711-19.

Higgins, Polly, Damien Short, and Nigel South. 2013. "Protecting the Planet: A Proposal for a Law of Ecocide." Crime, Law and Social Change 59 (3): 251-66.

Hugues, Carys. 2019. "Action Between the Legal and the Illegal: ALegality as a Political- Legal Strategy." Social and Legal Studies 28 (4): 470-92. 
Icaza, Rosalba. 2015. "The Permanent People's Tribunals and Indigenous People's Struggles in Mexico: Between Coloniality and Epistemic Justice?" Palgrave Communications, Article number 15020. https://doi.org/10.1057/palcomms.2015.20.

Jouve, Edmond. 1981. "Du tribunal de Nuremberg au Tribunal permanent des peuples" [From the Nuremberg tribunal to the Permanent People's tribunal]. Politique étrangère 46 (3): 669-75.

Jouzel, Jean-Noël, and Giovanni Prete. 2015. "Becoming a Victim of Pesticides: Legal Action and Its Effects on the Mobilisation of Affected Farmworkers." Sociologie du Travail 57:63-80.

Kirsch, Stuart. 2003. "Mining and Environmental Human Rights in Papua New Guinea." In Transnational Corporations and Human Rights, edited by J. G. Frynas and S. Pegg, 115-136. London: Palgrave Macmillan.

2012. "Juridification of Indigenous Politics." In Law Against the State: Ethno- graphic Forays into Law's Transformations, edited by Julia Eckert, Brian Donahoe, Christian Strümpell, and Zerrin Ozlem Biner, 23-43. Cambridge: Cambridge University Press.

Klinghoffer, Arthur Jay, and Judith Apter Klinghoffer. 2002. International Citizens' Tri- bunals: Mobilizing Public Opinion to Advance Human Rights. New York: Palgrave.

Lambert-Abdelgawad, Elisabeth. 2006. "La prolifération de tribunaux parallèles pour la dénonciation des crimes internationaux, quelle leçon de justice ?" [Multiplication of unofficial courts denouncing international crimes: What lesson of justice is learned?] Revue des sciences criminelles et de droit pénal comparé no. 1:170-82.

Lay, Bronwyn, Laurent Neyret, Damien Short, Michael Urs Baumgartner, and Antonio Oposa, Jr. 2015. "Timely and Necessary: Ecocide Law as Urgent and Emerging." Journal Jurisprudence (28): 431-52.

Le Bris, Catherine. 2017 "Commentaire de l'Avis consultatif du Tribunal Monsanto." [Comments on the Monsanto tribunal's advisory opinion]. Revue Droit de l'environnement (257): 232-36. 
Staging International Environmental Justice: The International Monsanto Tribunal by Giovanni Prete and Christel Cournil, in « Desire for Justice, Desire for Law: An Ethnography of Peoples' Tribunals ", PoLAR: Political and Legal Anthropology Review, Vol. 42, Number 2, pp. 191-209, November 2019

Mackenzie, Ruth, and Philippe Sands. 2003. "International Courts and Tribunals and the Independence of the International Judge." Harvard International Law Journal 44 (1): 271-85.

Maganda, Carmen. 2009. "Water Management Practices on Trial: The Tribunal Latinoamerica del Agua and the Creation of Public Space for Social Participation in Water Politics." In Social Participation in Water Governance and Management: Critical and Global Perspectives, edited by Kate Berry and Eric Mollard, 26588. London: Earthscan.

Maloney, Michelle. 2016. "Building an Alternative Jurisprudence for the Earth: The International Rights of Nature Tribunal." Vermont Law Review (41): 129-42.

Malviya, Chetna, and Laura Canali. Forthcoming. "Les procès fictifs, une réaction pertinente à l'inapplication du droit ?" [Fictional trials, a relevant reaction to law unenforcement?]. In L'inapplication du droit, edited by Romain Le Boeuf and Olivier Le Bot. Aix-enProvence, France: DICE Confluence des droits.

Maurin, Jost, 2016. "Wie ,böse" ist Monsanto wirklich?", Tageszeitung, October 14. https:/taz.de/Kritik-amSaatgutkonzern-imFaktencheck/!5345427\&s monsanto tribunal/.

Mayr, Teresa F., and Jelka Mayr-Singer. 2016. "Keep the Wheels Spinning: The Contributions of Advisory Opinions of the International Court of Justice to the Development of International Law." Heidelberg Journal of International Law 76 (2): 425-49.

McCormack, Fiona. 2016. "Indigenous Claims: Hearings, Settlements, and Neoliberal Silencing." PoLAR: Political and Legal Anthropology Review 39 (2): 226-43.

Merry, Sally Engle. 1996. "Legal Vernacularization and Ka Ho'okolokolonui Kanaka Maoli, The People's International Tribunal, Hawai'i 1993." PoLAR: Political and Legal Anthropology Review 19 (1): 67-82.

Minet, Pascaline. 2016. "Monsanto est-il coupable d"écocide'?," Le Temps, October 13. https://www.letemps.ch/sciences/monsantoestil-coupable-decocide. 
Staging International Environmental Justice: The International Monsanto Tribunal by Giovanni Prete and Christel Cournil, in « Desire for Justice, Desire for Law: An Ethnography of Peoples' Tribunals ", PoLAR: Political and Legal Anthropology Review, Vol. 42, Number 2, pp. 191-209, November 2019

Moita, Luis. 2015. "Opinion Tribunals and the Permanent People's Tribunal." JANUS.NET e-journal of International Relations 6 (1): May-October.

http://observare.ual.pt/janus.net/images/stories/PDF/vol6 n1/en/e n vol6 n1 art3.pdf.

Neyret, Laurent. 2014. "Pour la reconnaissance du crime d'écocide" [Advocating ecocide recognition]. Revue juridique de l'environnement 39 (HS 1) : 177-93.

Pieret, Julien. 2015. "Conclusions : Etudier les droits humains pour mieux comprendre les mouvements sociaux?" [Conclusions: Studying human rights to understand social movements?] Revue interdisciplinaire d'études juridiques 73 (2): 167-88.

Poissonnier, Ghislain. 2017. "Tribunal international Monsanto : portée de l'avis consultatif- Tribunal international Monsanto 18 avril 2017." [International Monsanto tribunal: Significance of the advisory opinion]. Recueil Dalloz 20:1123.

Riles, Annelise. 2000. The Network Inside Out. Ann Arbor: University of Michigan Press.

Robin, Marie-Monique. 2008. Le monde selon Monsanto : De la dioxine aux OGM, une multinationale qui vous veut du bien. [The world according to Monsanto: From dioxin to GMOs, a global firm that wants what is good for you]. Paris: La découverte.

2017. Roundup Facing Its Judges (Le Roundup face à ses juges). Paris: La découverte.

Senapathy, Kavin. 2015. "No, Monsanto Is Not Going on Trial for Crimes Against Humanity." Forbes, December 7. https://www.forbes.com/sites/kavinsenapathy/2015/12/07/nomonsanto-is-not-going-on-trial-for-crimes-againsthumanity/\#6f7e7655759f.

Simm, Gabrielle, and Andrew Byrnes. 2014. 'International 'Peoples' Tribunals in Asia: Political Theatre, Juridical Farce, or Meaningful Intervention?" Asian Journal of International Law 4 (1): 103-24.

Tandoc, Jr., Edson C., and Bruno Takahashi. 2014. "Playing a Crusader Role or Just Playing by the Rules? Role Conceptions 
Staging International Environmental Justice: The International Monsanto Tribunal by Giovanni Prete and Christel Cournil, in « Desire for Justice, Desire for Law: An Ethnography of Peoples' Tribunals », PoLAR: Political and Legal Anthropology Review, Vol. 42, Number 2, pp. 191-209, November 2019

and Role Inconsistencies among Environmental Journalists." Journalism 15 (7): 889-907.

Vanhala, Lisa. 2012. "The Paradox of Legal Mobilization by the UK Environmental Movement." Law \& Society Review 46 (3): 523-56.

Vidal, John. 2016. "GM seed firm Monsanto dismisses 'moral trial' as a staged stunt", The Guardian, October 13. https://www.theguardian.com/globaldevelopment/2016/oct/13/monsanto-staged-stunt-gm-seed-firmfaces-moral-trial.

Wilson, Richard Ashby. 2016. "Expert Evidence on Trial: Social Researchers in the International Criminal Courtroom." American Ethnologist 43 (4): 730-44.

Woods, Kerri. 2010. Human Rights and Environmental Sustainability. Cheltenham, UK: Edward Elgar Publishing.

Zunino, Marcos. 2016. "Subversive Justice: The Russell Vietnam War Crimes Tribunal and Transitional Justice." International Journal of Transitional Justice 10 (2) : 211-29 